\title{
PENGEMBANGAN MEDIA PEMBELAJARAN POP-UP BOOK DALAM PEMBELAJARAN KOSAKATA DASAR BAHASA JEPANGBAGI SISWA SD MUTIARA SINGARAJA
}

\author{
Mebbie H. L' ${ }^{1}$ I. W. Sadyana ${ }^{2}$, K. E. K. Adnyani ${ }^{3}$ \\ ${ }^{123}$ Jurusan Pendidikan Bahasa Jepang, Universitas Pendidikan Ganesha, Singaraja,Bali \\ e-mail: lie.haouk@undiksha.ac.id \\ wayan.sadyana@undiksha.ac.id krishna.adnyani@undiksha.ac.id
}

\begin{abstract}
Abstrak
Tujuan Tujuan penelitian ini adalah menghasilkan media pembelajaran yang interaktif untuk memudahkan siswa dalam mempelajari kosakata bahasa Jepang dasar di SD Mutiara Singaraja. Model pengembangan yang digunakan dalam penelitian ini adalah ADDIE (Analysis-Design-DevelopImplement-Evaluate). Dalam penelitian ini, digunakan metode (1) observasi lapangan, (2) wawancara, dan (3) kuesioner berupa angket uji ahli (uji ahli isi, uji ahli desain dan uji ahli kelayakan) untuk membantu proses pengembangan dan perbaikan produk. Berdasarkan angket uji ahli, persentase total skor untuk uji ahli isi adalah 81,3 dengan kualifikasi 'baik'; pada angket uji ahli desain persentase total skor adalah 99 dengan kualifikasi 'sangat baik'; dan pada angket uji kelayakan, persentase total skor adalah 95,72 dengan kualifikasi 'sangat baik'. Dengan demikian berdasarkan hasil analisis data tersebut dapat disimpulkan bahwa pengembangan pop-up book bagi siswa SD Mutiara Singaraja sudah memiliki usability yang sangat baik dan siap digunakan untuk membantu siswa dalam memahami kosakata bahasa Jepang dasar secara interaktif.
\end{abstract}

Kata Kunci: Pengembangan media, Pop-up Book, media pembelajaran, kosakata dasar bahasa jepang.

\section{要旨}

本研究の目的は、ムティアラシンガラジャ小学校で基本的な日本語の単語を学習するのを容易にする ための双方向学習教材の作成である。研究で使用した開発モデルはADDIE

(分析、設計、開発、実装、評価)である。本研究で用いるデータは、(1) 授業観察、

(2) インタビュー、

（3）専門家への質疑アンケート(含量、デザイン、実現可能性検討）により収集し、それを製品開発と 改善過程を支援するために使用した。専門家へのアンケートの結果、含量の資格が「良い」、総点は 8.13点であり、デザイン専門家のアンケートでは資格が「非常に良い」、総点は99点であった。それ に、実現可能性アンケートでは資格が「非常に良い」、総点は95.72点であった。データ分析の結果と して、ポップアップブックはムティアラシンガラジャ小学校にとって良い使いやすさを持ち、対話式 に日本語の単語を覚えるように適用されてます。

キーワード : メディア開発、ポップアップブック、学習メディア、日本語基礎語彙。

\section{Pendahuluan}

Salah satu faktor penunjang dalam proses belajar mengajar di tingkat dasar adalah media pembelajaran yang digunakan oleh pengajar kepada siswanya. Dalam sistem pendidikan modern, fungsi guru sebagai agen penyampai pesan-pesan pendidikan tampaknya perlu dibantu dengan media pendidikan yang interaktif, agar proses belajar mengajar pada khususnya dan proses pendidikan pada umumnya dapat berlangsung secara efektif dan efisien. Hal itu disebabkan antara lain, materi pembelajarannyang akan disampaikan semakin beragam dan luas mengingat perkembangan teknologi yang semakin pesat.

Melalui penggunaan media yang tepat dan sesuai dengan tujuan pembelajaran, maka tujuan pembelajaran akan mudah tercapai karena media pembelajaran memungkinkan keseragaman pengamatan dan presepsi bagi pengalaman belajar siswa, membangkitkan motivasi belajar siswa, serta dapat menyajikan informasi belajar yang dapat diulang menurut 
kebutuhan. Kegiatan pembelajaran itu sendiri membutuhkan alat bantu yang digunakan sebagai media dalam pembelajaran.

Bahasa asing khususnya bahasa Jepang adalah pelajaran yang cukup sulit untuk dipelajari selain bahasa-bahasa asing lainnya, apalagi diperuntukkan bagi siswa sekolah dasar dan kosakata yang sulit dimengerti adalah tantangan tersendiri bagi pengajar untuk memberikan pesan-pesan pendidikan.

Seperti halnya penelitian sejenis yang pernah dilakukan sebelumnya yaitu penelitian experiment dengan penelitian Single Subject Research (SSR) yang meneliti keefektifan media ajar berupa pop-up terhadap pemahaman konsep hewan dalam pembelajaran IPA pada siswa Tunagrahita kategori sedang, dengan hasil penelitian yang menunjukkan bahwa media pop-up efektif terhadap pemahaman konsep hewan dalam pembelajaran IPA pada siswa Tunagrahita kategori sedang kelas IV SDLB di SLB N 1 Sleman (Istasfi, 2016). Selain itu terdapat penelitian sejenis dan sudah pernah dilakukan sebelumnya yang meneliti mengenai media pop-up book berbasis budaya lokal untuk siswa sekolah dasar (Sholeh, 2017) yang menggunakan model penelitian pengembangan ADDIE (analysis, design, development, implementation, evaluation). Agar dapat menjadi media yang bisa dimanfaatkan oleh pengajar khususnya SD Mutiara Singaraja, diputuskan untuk mengkolaborasikan pop-up book dengan kosakata dasar bahasa Jepang yang tetap berisikan unsur pembelajaran dan imajinasi. Pop-up book ini dibuat agar pembelajaran lebih menarik dari pembelajaran yang menggunakan media yang seperti biasanya (buku LKS, Sakura, kamus bahasa Jepang, dll).

Dengan melihat betapa pentingnya media pembelajaran bergambar yang menarik dalam peningkatan kemampuan pembendaharaan kosa kata dasar bahasa Jepang, maka "Pengembangan Media Pembelajaran Pop-up Book dalam Pembelajaran Kosa Kata dasar Bahasa Jepang Bagi Siswa SD Mutiara Singaraja" dipilih sebagai judul yang tepat untuk penelitian ini. Melalui pengembangan media pembelajaran pop-up book ini diharapkan dapat membantu siswa agar lebih mudah dalam memahami materi pembelajaran, serta dapat memudahkan pengajar untuk menjelaskan materi dalam kemasan yang lebih menarik minat siswa.

Ditinjau dari latar belakang yang penulis sampaikan, maka dapat dirumuskan permasalahan yaitu "Bagaimana mengembangkan media pembelajaran yang interaktif dalam membantu memudahkan siswa mempelajari kosakata bahasa Jepang dasar di SD Mutiara Singaraja".

Dalam penelitian ini tujuan yang diharapkan untuk menghasilkan media pembelajaran yang interaktif dalam membantu memudahkan siswa mempelajari kosakata bahasa Jepang dasar di SD Mutiara Singaraja.

Dalam penelitian ini diharapkan dapat memberikan manfaat dan kontribusi yang positif pada semua pihak. Berikut adalah manfaat dari penelitian ini baik secara teoritis maupun secara praktis:

1. Manfaat Teoritis

Penelitian ini diharapkan dapat membantu mempermudah siswa dalam memahami kosakata bahasa Jepang dasar secara interaktif.

2. Manfaat Praktis

a. Bagi Peneliti

Dengan mengembangkan media pembelajaran ini diharapkan dapat menambah wawasan dan pengetahuan objek yang diteliti dan dapat membantu memenuhi kebutuhan berdasarkan permintaan guru dalam mempermudah siswa memahami kosakata.

b. Bagi Siswa

Dengan adanya media pembelajaran ini diharapkan dapat menambah wawasan siswa dan memudahkan siswa dalam memahami kosakata bahasa Jepang dasar secara menyenangkan.

c. Bagi Peneliti Lain

Dari hasil penelitian dan pengembangan media pembelajaran ini diharapkan dapat menjadi acuan dalam melakukan penelitian yang relevan.

Adapun definisi konseptual penelitian ini adalah sebagai berikut: 
1. Penelitian dan pengembangan adalah metode penelitian yang digunakan untuk menghasilkan produk tertentu dan menguji keefektifan produk (Sugiono, 2014).

2. Media pembelajaran adalah segala sesuatu yang dapat digunakan untuk menyalurkan pesan dari pengirim kepada penerima pesan. Dalam hal ini adalah proses merangsang pikiran, perasaan, perhatian, dan minat siswa sehingga proses belajar dapat terjalin (Sadiman, 1993).

3. kosakata adalah unsur bahasa yang diucapkan atau ditulis yang merupakan perwujudan kesatuan perasaan dan pikiran yang terdapat dalam berbahasa (KBBI, 2003).

\section{Metode}

\section{Model Penelitian ADDIE}

Model yang menjadi acuan dalam pengembangan Pop-up book pada mata pelajaran bahasa Jepang khususnya dalam ekstrakurikuler bahasa Jepang di SD Mutiara adalah model ADDIE merupakan salah satu model desain pembelajaran sistematik. Menurut Benny A. (2009; 128-132), terdapat satu model desain pembelajaran yang sifatnya lebih generik yaitu model ADDIE (Analysis-Design-Develop-Implement-Evaluate).

2. Prosedur Penelitian Pengembangan

Model desain pembelajaran ADDIE ini terdiri atas lima langka kegiatan namun pada penelitian ini dimodifikasi mendadi 3 tahapan, yaitu sebagai berikut.

a.Analisa (analysis)

Dari hasil analisa, berdasarkan pengambilan data berupa wawancara dan observasi dapat diketahui bahwa siswa kelas IV, V, dan VI di SD Mutiara Singaraja memiliki minat belajar yang tinggi dalam pembelajara bahasa asing khususnya dalam mata pelajaran bahasa Jepang. Namun anak-anak yang awalnya sangat antusias dengan mata pelajaran baru (bahasa Jepang) itu makin berkurang, dikarenakan media belajar yang kurang memadai dan media belajar khusus anak didik sekolah dasar untuk pembelajaran bahasa Jepang belum ada.

Cukup sulit bagi pengajar untuk membuat inovasi dalam proses belajar mengajar jika hanya mengandalkan buku Sakura yang harusnya digunakan untuk siswa SMA dan dipaksakan untuk diajarkan kepada siswa sekolah dasar. Setelah melakukan wawancara terstruktur di kediaman narasumber (pengajar), dapat diambil garis besar permasalahan dalam proses belajar mengajar khususnya dalam mata pelajaran bahasa Jepang untuk siswa sekolah dasar di SD Mutiara Singaraja, yaitu: buku pembelajaran yang menarik untuk menambah minat belajar dan keingin tahuan siswa mempelajari mata pelajaran bahasa Jepang yang menurut siswa cukup sulit untuk dipelajari; kemudian permasalahan lain dalam menjelaskan kepada siswa, materi yang membutuhkan beberapa alat peraga (gambargambar).

b.Perancangan (desain)

Hal yang dilakukan dalam tahap perancangan ini: pertama, merumuskan rumusan masalah dari hasil wawancara dan observasi yang didapat; kedua, membuat desain awal secara kasar dari rumusan masalah dan tujuan dibuatnya media pop-up book yang direncanakan; ketiga, dipertimbangkan sumber-sumber pendukung lain, semisal sumber belajar yang relevan, lingkungan belajar yang seperti apa yang sesuai dengan penggunaan media pembelajaran yang akan dikembangkan, dan kebutuhan dari pembelajaran bahasa Jepang khususnya dalam ekstrakurikuler bahasa Jepang di SD Mutiara Singaraja.

c.Pengembangan (development)

Dalam proses pengembangan adalah tahap mewujudkan buku tiga dimensi atau popup book menjadi kenyataan. Dalam kata lain, diperlukan desain berupa software untuk merancang tata letak dalam buku bergambar tiga dimensi perhalaman agar mempermudah dalam melakukan perbaikan untuk menghasilkan buku tiga dimensi yang layak digunakan bagi siswa SD Mutiara Singaraja nantinya. Kemudian dilanjutkan dengan tahap perakitan, yang meggunakan beberapa alat potong dan perekat.

Dalam langkah pengembangan ini, meliputi kegiatan membuat, membeli, dan memodifikasi media ajar. Dengan kata lain, mencakup kegiatan memilih, menentukan 
metode, media serta strategi pembelajaran yang sesuai untuk digunakan dalam menyampaikan materi dalam buku tiga dimensi ini.

Kemudian dilanjutkan pada tahap pengumpulan data dengan metode kuesioner dengan menggunakan angket uji ahli (uji ahli isi, kelayakan dan desain) dan setelah dilakukan pengumpulan data berupa angket uji ahli isi, kelayakan dan desain dilanjutkan dengan penyempurnaan produk berdasarkan komentar dan saran yang didapatkan dari tahap uji ahli.

3. Uji Coba Produk

Tahap uji coba produk harus dilakukan untuk mengetahui apakah produk yang dikembangkan sudah layak digunakan atau belum, sebelum melakukan tahap efektivitas produk. Tahap uji coba produk dalam penelitian pengembangan ini terdiri atas:

a.Desain Uji Coba

Pada desain uji coba, dalam mengembangkan bahan ajar pop-up book bagi siswa SD Mutiara Singaraja menggunakan desain deskriptif yang diuji validitasnya hingga tahap uji ahli meliputi uji ahli isi, uji ahli kelayakan dan uji ahli desain. Tinjauan dari uji ahli dimaksudkan untuk memperoleh penilaian, saran dan pendapat terhadap validasi isi bahan ajar yang dikembangkan.

b.Subjek Uji Coba

Subjek pada uji ahli produk penelitian ini adalah dosen Pendidikan Bahasa Jepang yang akan menguji kelayakan mengenai isi dari materi dalam produk pengembangan pop-up book. Uji ahli isi digunakan untuk mengetahui mengenai kelayakan materi dan media dari produk yang ditawarkan sebelum diuji cobakan produk kepada siswa dan pengajar.

Sedangkan untuk ahli desain dan kelayakanakan dilakukan oleh dosen ahli dan pengajar yang memiliki wewenang dalam menilai dan menguji kelayakan produk. Oleh karena itu, peneliti akan menggunakan tiga uji ahli meliputi isi, desain dan uji ahli kelayakan.

c.Jenis Data

Jenis data dalam penelitian ini adalah angket, data yang dikumpulkan merupakan penilaian, tanggapan dan saran-saran yang diperoleh dari para ahli isi di Program Studi Pendidikan Bahasa Jepang, uji ahli kelayakan dengan guru bahasa Jepang di SD Mutiara Singaraja dan ahli desain dengan dosen Komunikasi Visual di ISI Denpasar. Data tersebut digunakan sebagai pedoman untuk merevisi produk yang dikembangkan.

4. Instrumen Pengumpulan Data

Metode pengumpulan data dan instrument penelitian pada penelitian ini adalah instrument yang dipakai sebagai alat untuk mengukur validitas dan efektivitas dari rancangan yang telah dibuat. Penelitian ini menggunakan tiga instrumen penelitian yang digunakan untuk mengumpulkan dan menganalis is data, meliputi: observasi lapangan; wawancara; dan kuesioner berupa angket uji ahli yang dibagi menjadi tiga bagian yaitu uji ahli isi, uji ahli desain dan uji ahli kelayakan yang nantinya akan digunakan sebagai acuan dalam pengembangan dan perbaikan produk.

a. Pengamatan (observation)

Observasi pada penelitian ini adalah observasi partisipasi, yaitu observasi yang melibatkan penelitian sebagai observer secara langsung dalam kegiatan yang dilakukan dilapangan. Observasi dilakukan pada tanggal 25 Juli 2018 dan 18 September 2018 di SD Mutiara Singaraja dengan turut serta mengajar dan melihat potensi anak-anak didik. Kemudian, melihat bagaimana respons anak-anak selama proses pembelajaran berlangsung. Dalam tahap observasi di kelas, dapat disimpulkan bahwa dengan penggunaan metode yang tepat menggabungkan metode mengajar bermain sambil belajar dapat memicu daya serap siswa, sehingga penyampaian materi menjadi lebih efektif.

b. Wawancara

Aspek pedoman wawancara dalam proses pengambilan data dapat dibedakan menjadi tiga jenis yaitu: wawancara terstruktur; tidak terstruktur dan kombinasi (Darmani, 2014:311). Wawancara yang dilakukan dalam penelitian ini dilakukan dengan guru Ekstrakurikuler Bahasa Jepang di SD Mutiara Singaraja. Wawancara dilakukan secara kombinasi antara wawancara terstruktur dan tidak terstruktur. Wawancara ini dilakukan di kediaman narasumber pada 15 Juni 2018 dan 6 Agustus 2018. 


\section{c. Angket}

Pada penelitian ini, angket digunakan pada saat menganalisis proses uji coba ahli pada uji ahli isi, kelayakan dan uji ahli desain.

Data kuantitatif berupa penilaian validator, praktisi dan siswa dianalisis dengan deskriptif kuantitatif. Teknik analisis ini digunakan untuk mengolah data yang diperoleh melalui angket dalam bentuk deskriptif persentase. Rumus yang digunakan untuk menghitung persentase dari masing-masing subjek sebagai berikut.

Persentase $=$

Keterangan:

$\sum \mathrm{x} \quad$ : jumlah skor

SMI : skor maksimal ideal

Persentase keseluruhan subjek dapat dihitung menggunakan rumus sebagai berikut.

Persentase $=$

Keterangan:

$f$ : jumlah persentase keseluruhan subjek

$\mathrm{N}$ : banyak subjek

Hasil persentase tersebut menjadi dasar penilaian kelayakan bahan ajar, seperti yang ditunjukan pada tabel 1.

Tabel 1. Hasil Persentase

Tingkat Pencapaian Kualifikasi Keterangan

$90 \%-100 \% \quad$ Sangat Baik Tidak perlu direvisi

$75 \%-89 \% \quad$ Baik Direvisi seperlunya

$65 \%-74 \% \quad$ Cukup Cukup banyak revisi

$55 \%-64 \% \quad$ Kurang Banyak Revisi

$0 \%-54 \% \quad$ Sangat Kurang Direvisi Total

(Tegeh, et al., 2014: 83)

5. Teknik Analisis Data

Data yang dikumpulkan dari instrument yang telah diisi oleh responden ditabulasikan. Selanjutnya data informasi yang telah diperoleh dari instrument angket dianalisis dengan pendekatan deskriptif kualitatif.

\section{Hasil dan Pembahasan}

\section{Hasil Penelitian}

a. Penyajian Data Uji Coba

Buku yang dikembangkan dalam penelitian ini adalah pop-up book atau buku bergambar tiga dimensi yang memuat berbagai kosakata dasar bahasa Jepang bagi siswa SD Mutiara Singaraja. Buku ini menyajikan materi meliputi: (1) keluarga; (2) kegiatan sehari-hari; (3) makanan dan minuman; (4) nama hewan; dan (5) kegemaran dalam bahasa Jepang. Selain itu dalam buku ini, setiap bab terdapat ilustrasi yang akan membantu siswa dalam memahami materi dan membuat siswa termotivasi untuk mempelajari bahasa Jepang secara menyenangkan atau belajar sambil bermain yang sesuai pada anak diusia terebut.

Buku pop-up ini digunakan bagi siswa SD Mutiara Singaraja yang mengikuti ekstrakurikuler bahasa Jepang, baik semester ganjil dan genap. Pengajar bisa mengugunakan media ini kapanpun ketika siswa mulai bosan dan merasa kurang termotivasi selama proses pembelajaran berlangsung. Ketika suasana belajar yang mulai kurang kondusif, pengajar bisa mengunakan media ini untuk menarik perhatian siswa. Buku ini terdiri dari 5 bab yang disusun sesuai analisis kebutuhan melalui observasi dan wawancara serta modul yang ada. 
Bagan yang menggambarkan isi pop-up book yang berjudul Kira-Kira Pop-Up Easy Learning Japanese Pop-up dapat dilihat pada gambar 1.

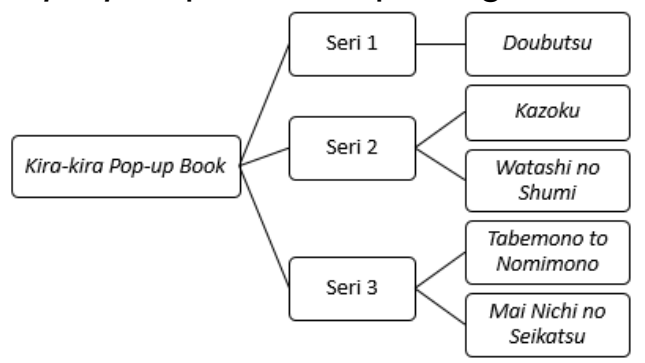

Gambar 1. Bagan Isi Buku

Buku ini disusun menggunakan huruf hiragana yang diikuti dengan huruf romaji sebagai cara baca, karena buku ajar bahasa Jepang untuk sekolah dasar dengan materi dan pemaparannya masih bersifat sederhana dan dibuat agar mudah dimengerti oleh siswa sekolah dasar khususnya siswa yang mengikuti ekstrakurikuler bahasa Jepang di SD Mutiara Singaraja. Selain itu, sesuai dengan hasil observasi bersama guru pengajar bahasa Jepang pada ekstrakurikuler bahasa Jepang di SD Mutiara Singaraja bahwa huruf hiragana dan katakana hanya dikenalkan secara sekilas kepada siswa.

Selanjutnya, ilustrasi yang digunakan merupakan ilustrasi yang dibuat manual menggunakan corel draw. Ilustrasi bukan diambil dari sumber lain untuk mengurangi salah presepsi makna dalam penggunaan buku pop-up. Adapun struktur dari buku yang telah disusun yaitu sebagai berikut.

a) Sampul depan

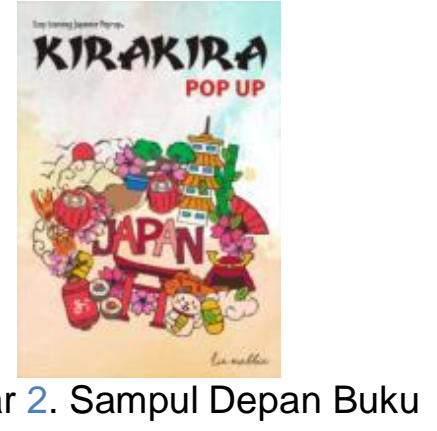

b) Kata pengantar

Kata pengantar dalam buku ini terdapat pada bagian awal buku diperuntukkan bagi siswa sekolah dasar Mutiara Singaraja. Kata pengantar menuliskan paparan dari isi buku secara singkat dan ucapan terimakasih kepada pihak yang telah membantu proses pembuatan buku.

c) Penyajian Kosakata

Kosakata disajikan dengan menggunakan huruf hiragana dan diikuti dengan cara baca menggunakan huruf romaji. Penyajian kosakata disetiap bab sudah dilengkapi dengan ilustrasi yang bertujuan menarik minat belajar siswa agar kosakata yang dipelajari mudah dipahami. Ilustrasi yang digunakan-pun disesuaikan dengan bentukbentuk yang mampu menarik minat siswa, tanpa menghilangkan makna dari ilustrasi. Kemudian, ilustrasi yang digunakan juga disesuaikan dengan kosakata bahasa Jepang. Penyajian dan penempatannya sesuai dengan konsep pop-up yang akan membuat gambar timbul. Penyajian kosakata dapat dilihat pada gambar 3 . 


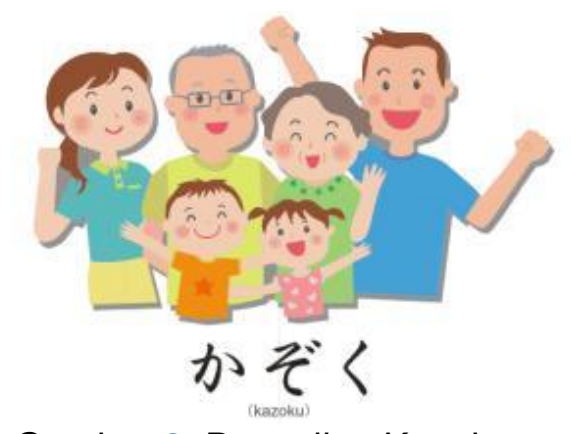

Gambar 3. Penyajian Kosakata

d) Penyajian Latihan

Latihan dalam buku Kira-kira pop-up disajikan untuk melatih dan membatu siswa dalam mengingat kembali materi kosakata. Latihan disajikan disetiap Bab yang sudah disesuaikan dengan kebutuhan belajar mengajar pada ekstrakurikuler bahasa Jepang bagi siswa SD Mutiara Singaraja. Penyajian latihan dapat dilihat pada gambar 4.

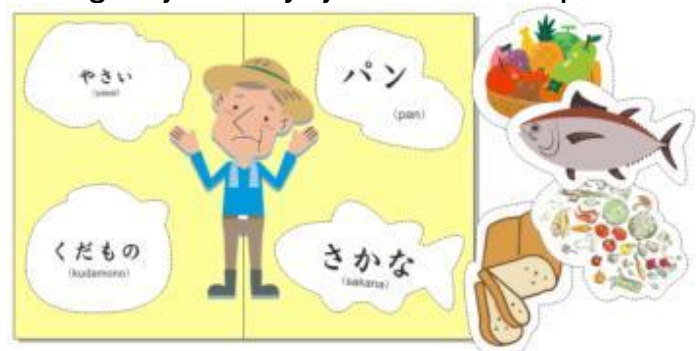

Gambar 4. Penyajian Latihan

e) Bab 1 - Keluarga

f) Sehari-hari

g) Bab 3 - Makanan dan Minuman

h) Bab 4 - Nama hewan

i) Bab 5 - Kegemaran

\section{b. Sistematika Penulisan}

Sistematika penulisan buku ajar yang menerapkan pembelajaran menggunakan ilustrasi merupakan bentuk adaptasi sistematika penulisan yang diadaptasi dari berbagai sumber. Buku Kira-kira pop-up diadaptasi dari bigbook namun dilakukan inovasi kembali dengan mengambil konsep ilustrasi timbul. Buku ini berukuran A3 $(29,7 \mathrm{~cm} \times 42 \mathrm{~cm})$ yang disesuaikan dengan kebutuhan belajar dan mengajar di SD Mutiara Singaraja. 2. Buku ajar ini menggunakan huruf Hiragana yang diikuti dengan cara baca (romaji) agar dapat memudahkan siswa dalam mempelajari huruf Jepang dan secara tidak langsung siswa mempelajari cara baca Hiragana dan Katakana yang dibantu dengan romaji. Adapun isi dari buku yang dikembangkan adalah rangkuman kosakata dasar bahasa Jepang beserta beberapa latihan yang diambil dari metode drill yang digunakan pengajar untuk melatih daya ingat siswa.

Dalam perakitan buku Kira-kira pop-up ini, peneliti menggunakan tekhnik VFolding, Pull-tabs, Pepshow dan flaps yang disesuaikan dengan ilustrasi disetiap babnya. Tekhnik perakitan digunakan lebih dari satu agar media dan ilustrasi didalamnya lebih bervariasi dan lebih mudah digunakan oleh pengajar maupun siswa. 


\section{c. Hasil Angket Uji Ahli}

Penilaian angket menggunakan penilaian skala 5 yakni Sangat Setuju (SS) $=5$, Setuju $(S)=4$, Cukup Setuju $(C S)=3$, Tidak Setuju $(T S)=2$, Sangat Tidak Setuju $(\mathrm{STS})=1$.

Angket uji ahli isi diberikan kepada Dosen Program Studi Pendidikan Bahasa Jepang, Universitas Pendidikan Ganesha. Angket ini diberikan pada tanggal 25 April 2019. Persentase total skor untuk uji ahli isi adalah 81,3 dengan kualifikasi 'baik'.

Angket uji ahli desain diberikan kepada Dosen Program Studi Desain Komunikasi Visual, ISI Denpasar. Angket ini diberikan pada tanggal 24 Januari 2019. Persentase total skor untuk uji ahli desain adalah 99 dengan kualifikasi 'sangat baik'.

Angket uji ahli kelayakan diberikan kepada pengajar ekstrakurikuler bahasa Jepang di SD Mutiara Singaraja. Angket ini diberikan pada tanggal 9 Juni 2019. Persentase total skor uji ahli kelayakan adalah 95,722 dengan kualifikasi 'sangat baik'.

d. Hasil Analisis Data

Sebelum menghasilkan buku ajar ajar yang layak digunakan, dilakukan tahap uji ahli terlebih dahulu agar menghasilkan produk yang berkualitas dan sesuai dengan kebutuhan responden. Buku ajar yang dihasilkan sudah melalui beberapa tahapan perbaikan dengan memperbaiki penggunakan bahasa Jepang dan desain buku agar sesuai dan menjadi lebih menarik. Tahap uji ahli dilakukan oleh tiga orang penguji ahli. Penguji ahli isi merupakan dosen Program Studi Pendidikan Bahasa Jepang Universitas Pendidikan Ganesha, uji ahli desain dari dosen Desain Komunikasi Visual - FSRD - ISI Denpasar dan uji ahli kelayakan dari pengajar ekstrakurikuler bahasa Jepang di SD Mutiara Singaraja.

Berdasarkan penilaian yang diberikan oleh ahli isi, buku ajar sudah sesuai dengan modul, namun pemilihan sub bab pada buku belum dipastikan sesuai dengan kebutuhan pengajar. Kemudian kesesuaian ilustrasi dengan materi sudah sesuai dengan saran perbaikan berupa: perbaikan kosakata sufu; soba; ha wo migikimasu; tori serta penyusunan ilustrasi bagan keluarga harus diperbaiki lagi. Ilustrasi-pun sudah menarik dan sesuai dengan kebutuhan anak didik di SD Mutiara Singaraja. Jenis kosakata yang digunakan sudah sesuai dengan kebutuhan pengajar dan sesuai dengan kebutuhan siswa di SD Mutiara Singaraja yang mempelajari kosakata bahasa Jepang dasar. Latihan dalam buku juga sudah sesuai dan sangat membantu pengajar beserta siswa, namun terdapat saran perbaikan agar pada setiap bab terdapat latihan sedikit saja. Buku sudah mampu mendorong siswa dalam berpikir positif. Keseuaian desain cover pada buku ajar dengan materi sudah sesuai karena mencerminkan ke-Jepangan. Dari keseluruhan penilaian oleh ahli terhadap aspek isi buku ajar, dapat disimpulkan bahwa isi buku ajar sudah layak dan sesuai.

Berdasarkan penilaian yang diberikan oleh ahli desain, Desain isi buku sangat menarik, dengan penempatan ilustrasi dan tulisan sesuai dan konsisten. Jarak antar teks dengan ilustrasi sudah sesuai berdasarkan ukuran buku. Penempatan huruf penjelas gambar tidak mengganggu pemahaman. Penempatan ilustrasi kerangka gambar sudah sesuai dengan ukuran buku. Penggunaan variasi huruf tidak berlebihan. Ilustrasi sudah mengungkapkan makna arti dari objek. Penyajian keseluruhan ilustrasi menarik. Gambar atau ilustrasi yang dihadirkan menarik, tokoh-tokoh dalam buku mencerminkan nuansa ceria anak-anak. Terdapat beberapa tambahan komentar dari ahli yaitu: ide untuk mengungkapkan pesan 
komunikatif; gambar yang dihadirkan sangat menarik; dan dengan adanya sedikit perbaikan buku ini akan sangat bermanfaat dalam pembelajaran khususnya bahas Jepang. Selamat.

Berdasarkan penilaian yang diberikan oleh ahli kelayakan, hal-hal yang perlu dinilai meliputi: kesesuaian materi dengan modul; kesesuaian ilustrasi dengan materi; kesesuaian ilustrasi dengan kebutuhan siswa sekolah dasar; dan keseuaian kegunaan produk. Terdapat komentar dan saran oleh ahli kelayakan yang adalah pengajar ekstrakurikuler bahasa Jepang di SD Mutiara Singaraja, meliputi: media pembelajaran bahasa Jepang untuk sekolah dasar khususnya tentang kosakata, saya rasa cukup menarik jika diaplikasikan dalam bentuk pop-upbook karena didalamnya terdapat konten-konten berupa gambar ilustrasi yang mampu menarik pusat perhatian anak-anak sehingga mereka bisa lebih mudah mempelajari dan memahami kosakata yang dimaksudkan dan menjadikan pembelajaran bahasa Jepang sebagai hal yang menyenangkan.

e. Revisi Produk

Berdasarkan saran dan komentar dari uji ahli desain, pada cover depan awal warna masih kurang menarik. Selain itu tulisan pada judul buku kurang mencerminkan identidas ke-Jepangan. Perlu ditambahkan lagi variasi pada cover bagian belakang. Tambahkan sedikit informasi tentang penulis pada cover belakang dapat dilihat pada gambar 5 .

Gambar 6 adalah hasil dari revisi yang disarankan oleh penguji ahli desain. Semua sudah disesuaikan dengan kebutuhan dan yang dikomentari oleh penguji. Dengan perubahan warna yang lebih manis dan mencolok, ditambah variasi pada cover belakang dan penambahan sedikit informasi tentang penulis.

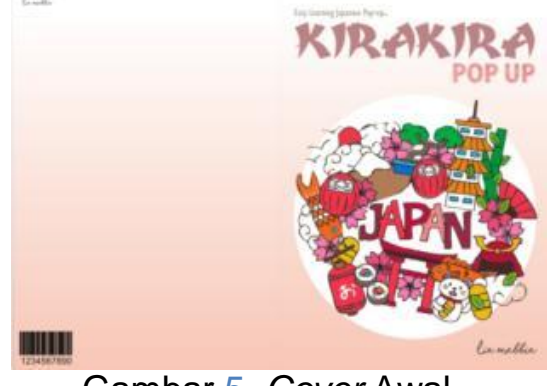

Gambar 5. Cover Awal

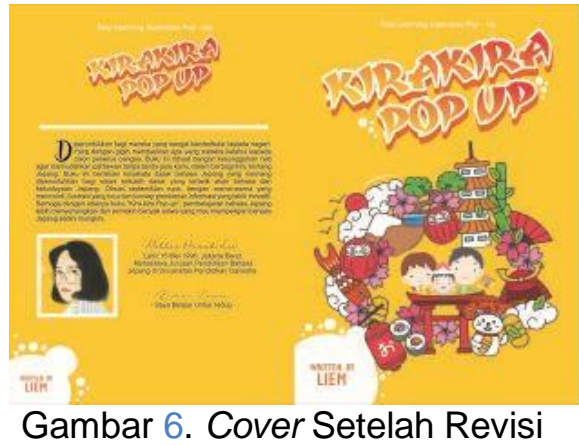

Berdasarkan uji ahli Isi terdapat komentar untuk memperbaiki bagan pada sub bab anggota keluarga agar menyusun bagan sesuai dengan urutan kakak laki-laki, kakak perempuan, saya, adik perempuan, adik laki-laki yang disusun berjajar dapat dilihat pada gambar 7 . 


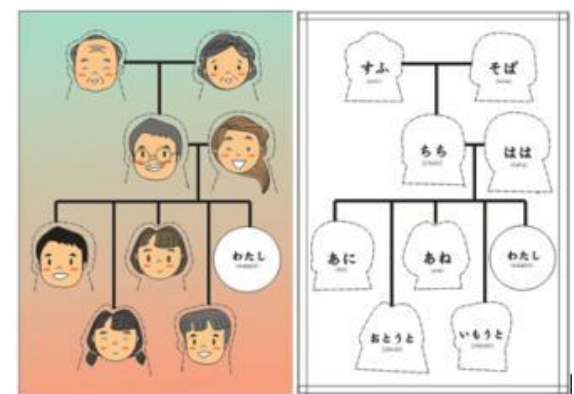

Gambar 7. Ketepatan Penempatan Ilustrasi Sebelum Revisi

Maka perbaikan bagan telah diperbaiki dengan cara mengulang bagan anggota keluarga. Hasil perbaikan dapat dilihat pada gambar 8 yang terlihat lebih baik.

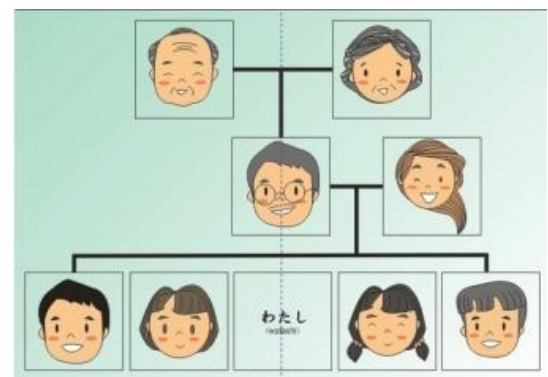

Gambar 8. Ketepatan Penempatan llustrasi Sesudah Direvisi

Berdasarkan uji ahli isi, terdapat saran dan perbaikan untuk merubah ilustrasi pada kosakata hon o yomimasu (dapat dilihat pada gambar 9) dengan ilustrasi lain yang lebih menggambarkan arti dari kosakata tersebut. Gambar 10 adalah ilustrasi dari revisi sebelumnya.

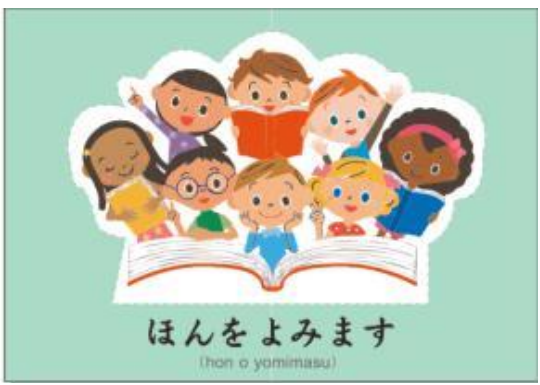

Gambar 9. Kesesuaian Ilustrasi Sebelum Revisi

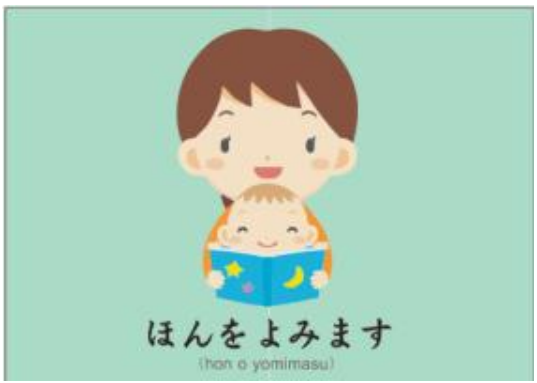

Gambar 10. Kesesuaian Ilustrasi Sesudah Revisi

Berikut adalah hasil revisi kesesuaian kosakata dengan ilustrasi, terdapat kesalahan penulisan kosakata pada bab doubutsu, kosakata tidak sesuai dengan gambar (dapat dilihat pada gambar 11), kemudian dilakukan revisi sesuai dengan saran oleh uji ahli isi. Gambar 12 adalah hasil revisi dari kesesuaian kosakata pada bab doubutsu. 


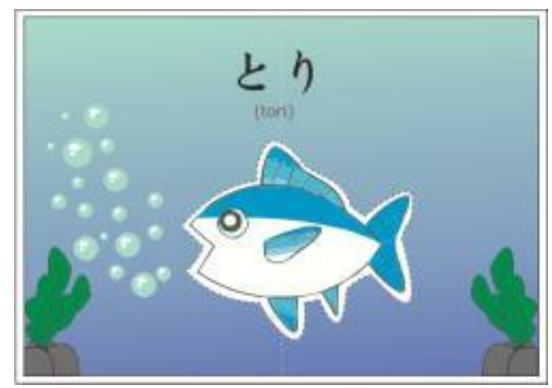

Gambar 11. Kesesuaian Kosakata Sebelum Revisi

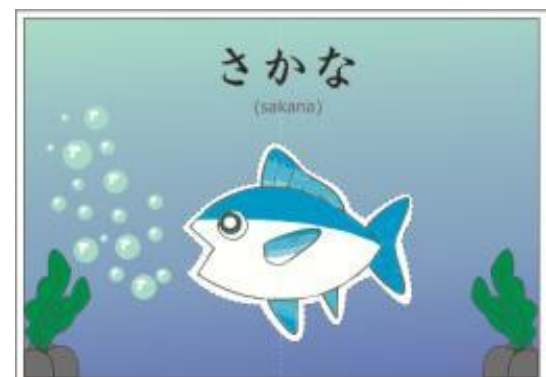

Gambar 12. Kesesuaian Kosakata Sesudah Revisi

\section{Pembahasan Hasil Penbelitian}

Berdasarkan latar belakang yang telah dipaparkan pada bab I, penelitian ini dilakukan karena sampai saat ini masih belum tersedianya buku bahasa Jepang dasar bagi siswa di SD Mutiara Singaraja.

Dalam penelitian ini untuk mengetahui produk dalam penelitian ini layak digunakan atau tidak, peneliti menggunakan metode penilaian menggunakan angket. Penilaian angket pada penelitian ini menggunakan penilaian skala 5 yakni: Sangat Setuju (SS) = 5; Setuju (S) = 4; Cukup Setuju $(C S)=3$; Tidak Setuju $(T S)=2$; Sangat Tidak Setuju $(\mathrm{STS})=1$. Berdasarkan hasil penyajian angket dalam tahap validasi uji ahli isi, uji ahli kelayakan dan uji ahli desain, hasil validasi menunjukkan bahwa tingkat validasi uji ahli isi berasa pada kualifikasi sesuai, sedangkan hasil uji ahli validasi uji ahli desain berada pada kualifikasi sangat sesuai. Sehingga dapat disimpulkan bahwa buku ini sudah layak dan sesuai.

Guru ekstra kurikuler bahasa Jepang di SD Mutiara Singaraja menjelaskan bahwa pengembangan buku ajar bahasa Jepang untuk siswa Sekolah Dasar sangat diharapkan karena pengenalan bahasa Jepang dasar yang paling sederhana dengan ilustrasi lebih tepatdikenalkan kepada siswa SD Mutiara Singaraja. Banyaknya buku yang beredar dipasaran namun tidak ada yang sesuai untuk siswa sekolah dasar yang baru mengenal bahasa Jepang.

Materi yang disajikan sudah disesuaikan dengan kebutuhan pengajaran ekstrakurikuler bahasa Jepang di SD Mutiara Singaraja. Materi disajikan agar siswa aktif dan kreatif di kelas dan meningkatkan keingintahuan dalam mempelajari bahasa Jepang tingkat dasar melalui inovasi pembelajaran lewat buku bergambar tiga dimensi.

Buku Kira-kira pop-up ini telah disusun berdasarkan model pengembangan ADDIE (Analysis-Design-Develop-Implement-Evaluate). Dimulai dari tahap: analysis dengan melakukan wawancara terbuka dan observasi lapangan; kemudian dilanjutkan dengan tahap design atau perancangan dengan menentukan format, konsep dan ilustrasi buku ajar; dilanjutkan dengan tahap development atau pengembangan yang adalah tahap eksekusi pembuatan produk dengan menggunakan modul sebagai acuan pembuatan produk; untuk tahap implementasi 
tidak diturut sertakan, dan dilanjutkan dengan tahap evaluation yang dilakukan dengan pengumpulan data verifikasi produk oleh uji ahli isi, uji ahli kelayakan dan uji ahli desain; kemudian setelah produk lolos uji ahli masih dilanjutkan dengan revisi dan penyempurnaan produk. Setelah penyempurnaan produk rampung, buku siap dirakit dan siap digunakan oleh pengajar.

Buku ini sudah layak digunakan sebagai buku ajar untuk siswa yang mengikuti ekstrakurikuler bahasa Jepang di SD Mutiara Singaraja karena sudah melewati tahap uji ahli isi, kelayakan dan desain. Kelayakan penggunaan bahasa Jepang pada buku ini sudah dinilai oleh ahli isi yang merupakan salah satu dosen pendidikan bahasa Jepang di Universitas Pendidikan Ganesha. Kelayakan penyajian buku ajar ini juga sudah dinilai oleh ahli desain yang merupakan salah satu dosen Desain kominikasi Visual di Universitas ISI (Institut Seni Indonesia) Denpasar dan pengajar ekstrakurikuler bahasa Jepang di SD Mutiara Singaraja.

Tanggapan guru bahasa Jepang di SD Mutiara Singaraja mengungkapkan bahwa buku yang dikembangkan ini sangat menarik untuk minat siswa dalam proses belajar mengajar bahasa Jepang dan adanya buku ajar yang sesuai dengan kemampuan pengetahuan serta karakteristik siswa menimbulkan sikap kompetitif siswa yang positif.

Berdasarkan paparan diatas, diharapkan buku Kira-kira pop-up untuk siswa kelas IV, V, VI SD Mutiara Singaraja ini dikembangkan sehingga dapat digunakan oleh guru dan siswa sebagai sumber belajar mengajar bahasa Jepang untuk meningkatkan keterampilan berbahasa Jepang.

\section{Implikasi Penelitian}

Berdasarkan hasil pembahasan, penelitian dan pengembangan ini memiliki implikasi yaitu buku ajar ini dapat digunakan untuk siswa yang mengikuti ekstrakurikuler bahasa Jepang di SD Mutiara Singaraja. Buku ajar ini membantu guru dalam proses belajar mengajar dalam kelas. Kemudian dapat membantu siswa agar lebih termotivasi dalam mempelajari bahasa Jepang dan dapat menguasai kosakata dasar bahasa Jepang.

\section{Simpulan dan Saran}

Simpulan yang dapat dirumuskan yaitu buku ajar yang dikembangkan di SD Mutiara Singaraja adalah buku ajar bahasa Jepang yang lebih menonjolkan pada ilustrasi sebagai penjelas kosakata dasar yang terdapat dalam buku dan dibuat timbul. Dibuat berwarna dengan ilustrasi yang lucu, agar menarik perhatian siswa selama proses pembelajaran berlangsung. Selain itu pada setiap bab terdapat huruf hiragana dan diikuti dengan huruf romaji atau cara baca dalam bahasa Jepang. Kemudian terdapat beberapa latihan yang akan membantu pengajar membuat siswa aktif selama proses pembelajaran. Kemudian latihan tersebut dapat dijadikan bahan evaluasi agar mengetahui perkembangan pengetahuan siswa.

Buku ini terdiri dari 5 bab yang disusun berdasarkan analisis kebutuhan melalui wawancara, observasi lapangan serta modul yang digunakan pengajar selama proses pembelajaran ekstrakurikuler bahasa Jepang SD Mutiara Singaraja. Terdiri dari 5 bab yang dibagi menjadi: bab I Kazoku - Anggota Keluarga; bab II Mai Ichi Nichi - Kegiatan Sehari-hari; bab III Tabemono Nomimono - Makanan dan Minuman; bab IV Doubutsu - Nama hewan; bab V Shumi - Kegemaran. Kemudian setiap bab terdapat latihan yang dapat membantu pengajar dalam melihat perkembangan siswa dalam mempelajari kosakata bahasa Jepang dasar.

Kepada guru diharapkan dapat memfasilitasi siswa dengan mengguanakan buku kirakira pop-up, baik dalam kelas maupun diluar kelas. Selain menggunakan kira-kira pop-up, guru juga diharapkan menggunakan video, flash card, maupun media lainnya untuk menunjang proses pembelajaran. 
Dari hasil penelitian dan pengembangan media pembelajaran ini diharapkan dapat menjadi acuan dalam melakukan penelitian yang relevan seperti melakukan pengembangan buku ajar berupa pop-up atau buku bergambar yang lebih inovatif bagi siswa sekolah dasar yang menerapkan pembelajaran bahasa Jepang baik ektrakurikuler maupun mata pelajaran wajib. Diharapkan peneliti lain mengembangkan buku pop-up untuk anak sekolah dasar kelas 1,2, dan 3 karena penelitian ini hanya menghasilkan media pop-up book untuk siswa kelas 4,5 dan 6 . Selain itu dihapakan akan mengembangkan kembali penelitian ini pada tahap implementation dan evaluation, karena pada penelitian ini hanya sampai pada tahap development.

\section{Daftar Pustaka}

Darmani Hamid. 2014. Metode Penelitian Pendidikan dan Sosial. Bandung: Alfabeta

Gay L.R. 1990. Educational Evaluation and Measurement: Competencies for Analysis and Aplplication. New York: Macmillan Publishing Compan. - Vol. second edition.

Ismawati, Esti. 2012. Telaah Kurikulum dan Pengembangan Bahan Ajar. Yogyakarta: Ombak.

Istasfi Nausyad Em'a. 2016. Keefektifan Media Pop Up terhadap Pemahaman Konsep Hewan dalam Pembelajaran IPA pada Siswa Tunagrahita Kategori Sedang Kelas IV SDLB di SLB N 1 Sleman. Yogyakarta: Program Studi

KBBI Online. 2003. KBBI Online (KBBI Web) Tersedia pada http://kbbi.web.id/ kosakata (diakses tanggal May 28, 2017).

Sadiman Arif S. 1993. Media Pendidikan: Pengertian, Pengembangan dan Pemanfaatannya. Jakarta: Raja Grafindo Persada.

Sugiyono. 2014. Metode Penelitian Kuantitatif Kualitatif dan $R \& D$, Cetakan kedua puluh. Jakarta : Alfabeta.

Tegeh Made, Jampel Nyoman and Pudjawan Ketut. 2014. Model Penelitian Pengembagan. Yogyakarta : Graha IImu. 